\title{
KENYAMANAN LIFT BAGI KAUM DIFABLE STUDI KASUS DI \\ R.S KASIH IBU, R.S ISLAM YARSIS DAN R.S MOEWARDI SURAKARTA
}

\author{
Wijiyanto, Samsudin \\ Program Studi Teknik Arsitektur, Fakultas Teknik, Universitas Muhammadiyah Surakarta \\ Jl. A. Yani Tromol Pos 1 Pabelan Kartasura Sukoharjo 57102 Telp 0271-717417 \\ E-mail: raidi_samsudin@yahoo.co.id
}

\begin{abstract}
ABSTRAK
Transportasi vertikal adalah transportasi yang digunakan untuk mengangkut sesuatu benda dari bawah ke atas atau moda transportasi yang direncanakan untuk memenuhi kebutuhan para penghuni untuk mendukung aktivitas pada gedung bertingkat. Transportasi vertikal terdiri dari lift (Elevator), tangga berjalan (Escalator), ramp, tangga, lift barang (Dumbwaiter) serta travator (Conveyor). Lift (Elevator) adalah suatu alat transportasi untuk mengangkut barang atau penumpang dari satu lantai ke lantai lainnya. Dalam setiap perencanaan lift harus diadakan dengan ketentuan perencanaan yang baik. Rumah sakit adalah sarana yang menyelenggarakan pelayanan jasa kesehatan kepada masyarakat. Untuk memberikan pelayanan yang baik, salah satu alat transportasi vertikal yang harus disediakan adalah lift yang mampu membawa pasien dari lantai satu ke lantaiu lainnya. Dalam penelitian ini, peneliti akan mencoba untuk mengetahui bagaimana kualitas transportasi vertikal dengan menggunakan metode perbandingan antara studi literatur tentang standar perencanaan transportasi vertikal dengan kondisi perencanaan transportasi vertikal (lift) yang ada di lapangan. Dengan mengetahui perbandingan antara literatur standar perencanaan lift dengan kondisi lift yang ada di lapangan maka dapat dikaji suatu persepsi, dengan melakukan perhitungan empiris dari kumpulan data yang ada dengan menggunakan formula hitung; sehingga diperoleh tabel perbandingan antara standar dengan kondisi eksisting lift di lapangan. Pengukuran kualitas transportasi vertikal dengan melakukan evaluasi menggunakan kriteria evaluasi. Penelitian ini menghasilkan kesimpulan bahwa penilaian tingkat keberhasilan pemakaian lift suatu bangunan dalam memberikan kepuasan kepada pemakai terutama untuk penyandang cacat fisik adalah cukup nyaman atau penggunaan elevator (lift) adalah sangat vital.
\end{abstract}

\section{Kata Kunci: lift, rumah sakit, difabel}

\section{PENDAHULUAN}

Mobilitas peralatan memainkan peran utama dalam membangun hidup dan kehidupan para penyandang cacat. Mayoritas orang-orang cacat telah memperoleh kemerdekaan serta kehilangan momentum kehidupan mereka dengan bantuan perangkat mobilitas yang dikembangkan secara ilmiah. Bahkan, alat-alat mobilitas yang berbeda adalah teman terbaik bagi orang-orang penyandang cacat.

Transportasi vertikal adalah transportasi yang digunakan untuk mengangkut sesuatu benda dari bawah ke atas atau moda transportasi yang direncanakan untuk memenuhi kebutuhan para penghuni untuk mendukung aktivitas pada gedung bertingkat. Transportasi vertikal terdiri dari lift (Elevator), tangga berjalan (Escalator), ramp, tangga, lift barang (Dumbwaiter) serta travator (Conveyor). Lift (Elevator) adalah suatu alat transportasi untuk mengangkut barang atau penumpang dari satu lantai ke lantai lainnya. Untuk itu dibutuhkan alat pengangkut. Dalam setiap perencanaan lift harus diadakan dengan ketentuan perencanaan yang baik. 
Rumah Sakit adalah sarana yang menyelenggarakan pelayanan kesehatan. Penelitian ini bertujuan untuk mengetahui bagaimana kualitas transportasi vertikal dengan menggunakan metode perbandingan antara studi literatur tentang standar perencanaan transportasi vertikal dengan kondisi perencanaan transportasi vertikal (lift) yang ada di lapangan.

\section{RUMUSAN PERMASALAHAN}

Permasalahan dirumuskan sebagai berikut: bagaimana prosentase tingkat kenyamanan sarana LIFT yang ada pada bangunan Rumah sakit sebagai sarana aksesibilitas untuk kaum difabel.

\section{TINJAUAN PUSTAKA}

Aksesbilitas adalah kemudahan yang disediakan bagi penyandang cacat guna mewujudkan kesamaan kesempatan dalam segala aspek kehidupan dan penghidupan. Aksessibel adalah suatu kondisi tapak atau bangunan, fasilitas atau bagian darinya yang memenuhi persyaratan teknis aksesibilitas berdasarkan standar standar yang berlaku Menurut Peraturan Menteri Pekerjaan Umum No. 30/PRT/M/2006 Tentang Persyaratan Teknis dan Aksesibilitas pada Bangunan Umum dan Lingkungan, asas aksesibilitas meliputi:

1. Kemudahan, yaitu setiap orang dapat mencapai semua tempat atau bangunan yang bersifat umum dalam suatu lingkungan.

2. Kegunaan, yaitu setiap orang dapat mempergunakan semua tempat atau bangunan yang bersifat umum dalam suatu lingkungan.

3. Keselamatan, yaitu Setiap bangunan yang bersifat umum dalam suatu lingkungan terbangun, harus memperlihatkan keselamatan bagi semua orang.

4. Kemandirian, yaitu setiap orang dapat mencapai, masuk mempergunakan semua tempat atau bangunan yang bersifat umum dalam suatu lingkungan dengan tanpa bantuan orang lain.

Kenyamanan untuk penyandang cacat merupakan hal yang sangat penting. Ada berbagai jenis perangkat mobilitas yang tersedia seperti, kursi roda, mobilitas skuter, angkat kursi, angkat lift kendaraan, pejalan, dan landai. Namun, untuk melayani kebutuhan mobilitas utama penyandang cacat perlu adanya analisis persyaratan peralatan atau sarana dan prasarana yang cocok untuk melayani kebutuhan kenyamanan bagi penderita cacat (Suryaning, 2008).

Kenyamanan lift adalah suatu kondisi nyaman pada alat yang digunakan untuk menaikkan dan menurunkan orang atau barang dengan standar - standar tertentu dimana lift tersebut mempunyai fasilitas fasilitas pendukung atau penunjang.

\section{Penggolongan Penderita Cacat Secara Umum}

Cacat merupakan kelainan pada organ tubuh makhluk hidup yang seharusnya tidak dimiliki oleh suatu organ tersebut. Program Kebijakan Pemerintah bagi penyandang cacat cenderung berbasis belas kasihan (charity), sehingga kurang memberdayakan penyandang cacat untuk terlibat dalam berbagai masalah. Kurangnya sosialisasi peraturan per-undang undangan tentang penyandang cacat menyebabkan perlakuan stakeholder unsur pemerintah dan swasta yang kurang peduli.

\section{Jenis-jenis Kecacatan}

Kecacatan dapat digolongkan menjadi 3 (tiga) bagian, di dalam buku Suluh Rehabilitasi Cacat Tubuh No. 39/XXX/1999 halaman 15, UU Nomor 4 tentang Penyandang Cacat yaitu sebagai berikut :

\section{a. Cacat Fisik,}

yaitu kecacatan yang mengakibatkan gangguan pada fungsi tubuh, terdiri dari:

1).Cacat Tubuh, diakibatkan oleh kelainan fungsi tubuh, terdiri dari sebagian anggota tubuh dan terganggunya syaraf motorik.

2).Cacat Netra yaitu cacat lihat dan cacat buta sama sekali

3).Cacat Rungu Wicara yaitu cacat rusaknya saluran alat pendengaran dan alat suara.

\section{b. Cacat Mental}

yaitu kelainan mental dan atau tingkah laku baik cacat bawaan maupun akibat dari penyakit.

\section{c. Cacat Fisik dan mental}

yaitu keadaan seseorang yang menyandang dua jenis kecacatan sekaligus. 
Dari jenis-jenis kecacatan di atas yang termasuk di dalam pembahasan adalah cacat tubuh.

\section{Penggolongan kecacatan}

Penggolongan kecacatan dalam pembahasan ini yaitu pada cacat fisik dengan kecacatan tubuhnya digolongkan, sebagai berikut:

a. Menurut penyebabnya yaitu diakibatkan kecelakaan lalu lintas atau insdustri, akibat penyakit folio dan TBC tulang, akibat peperangan atau kejahatan dan cacat sejak lahir.

b. Menurut bentuk kecacatan yaitu cacat amputasi tangan dan kaki, cacat kelumpuhan pada kedua kaki (paraplegia).

c. Menurut penggunaan alat bantu yaitu menggunakan alat bantu luar (tongkat, kursi roda, cruth, armpit), menggunakan alat bantu dalam (tangan/ kaki palsu, sepatu Orthopedi, bracal alat penguat kaki).

d. Menurut kemampuan gerak, yaitu :

- Ambuland Disablet: penderita yang tidak mengalami kesulitan yang cukup berarti untuk bergerak.

- Semi Ambuland Disablet: penderita yang mengalami sedikit kesulitan untuk bergerak.

Non Ambuland Disablet: penderita yang harus menggunakan alat bantu untuk bergerak (kursi roda).

\section{Transportasi Vertikal}

Menurut Juwana (2009), sistim transportasi vertikal adalah salah satu masalah yang menjadi pemikiran pertama pada perencanaan bangunan bertingkat banyak. Di dalam masalah transportasi vertikal tersebut kita mengenal berbagai alat dengan segala kekurangan dan kelebihannya.

Alat-alat transportasi vertikal diantaranya adalah ramp, tangga dan elevator

\section{Ramp}

Pengertian Ramp

Ramp memiliki definisi dan spesifikasi sebagai berikut (Azizah, 1999):

a. Adalah jalan atau lintasan miring (rata-rata 8-10 derajat) untuk gerak manusia pada suatu bangunan berlantai banyak. b. Adalah alat gerak manusia yang memadukan jarak horizontal dan vertikal.

c. Adalah alat transport manusia dan barang pada bangunan yang kurang dari 5 lantai.

d. Adalah sarana yang digunakan untuk mempermudah gerakan melintas, dan terutama pada bangunan umum seperti hotel, rumah sakit dan mall, agar mudah dalam mengangkut atau melintasi ketinggian yang berlainan.

\section{Tangga}

Tangga adalah alat transportasi vertikal pada bangunan yang mempunyai pijakan dan kemiringan yang digunakan untuk mencapai ketinggian tertentu. Tangga dibagi menjadi dua macam:

\section{Tangga Statis}

Keberadaan tangga statis pada bangunan dibagi menjadi:

a. Tangga Umum, macam-macamnya ada tangga lurus, tangga spiral (putar), tangga paralel, tangga sudut dan tangga kombinasi.

b. Tangga Darurat, untuk menyelamatkan diri dari terjadinya kebakaran atau keadaan darurat lainnya sehingga tangga ini harus dilindungi dari api dan asap.

\section{Tangga Berjalan (Escalator)}

Adalah tangga yang bisa bergerak karena adanya mesin penggerak yang bertenaga listrik. Escalator sangat cocok untuk pemakai dalam jumlah besar dalam bangunan berlantai yang tak begitu banyak.

\section{Elevator (Lift) \\ Pengertian Lift}

Menurut Juwana (2009), sebuah elevator atau lift adalah transportasi vertikal kendaraan yang efisien untuk orang atau barang bergerak antar lantai dari sebuah bangunan. Mereka umumnya didukung oleh motor listrik yang baik mendorong daya tarik kabel dan sistem penyeimbang, atau pompa hidrolik cairan untuk menaikkan piston silinder.

Elevator / lift merupakan instalasi transportasi vertikal (tegak lurus ke atas) yang mengangkut manusia atau barang atau keduanya dalam ruang berupa tabung atau sangkar yang digerakkan oleh mesin untuk 
mencapai ketinggian yang ditentukan / diinginkan.

Berdasarkan jenis penggunaannya, maka lift dibagi 4 jenis klasifikasi:

1. Bangunan Umum-Komersil (general purpose-commercial)

2. Perhotelan/Penginapan (Residential)

3. Institusional/Perkantoran (Institutional)

4. Pertokoan (Store)

Sebagai alat transportasi vertikal, elevator/lift memiliki persyaratan sebagai berikut:

1. Tidak menunggu lama (low waiting time)

2. Perlambatannya nyaman (smooth and rapid)

3. Percepatannya nyaman (comfortable acceleration)

4. Mempunyai kecepatan tinggi (rapid transportation)

5. Mempunyai pemberhentian yang otomatis (automatic level and landing)

6. Cepat menaikkan dan menurunkan penumpang

7. Digunakan pada bangunan dengan jumlah lantai $>4$.

\section{Spesifikasi Elevator / Lift}

1. Sifat Elevator:

- Mempunyai kapasitas muat yang terbatas.

- Digerakkan dengan bandul.

- Membutuhkan ruangan tersendiri untuk mesin dan keretanya.

2. Elemen Elevator:

- Magneting Landing Device

Untuk memberhentikan kereta elevator pada tiap lantai yang dituju, dengan toleransi maksimum $5 \mathrm{~mm}$ dari level lantai bersangkutan.

- Buffer

Buffer yang dipakai dari jenis Spring Buffer dan Oil Buffer, dimana bagian atas diberi lapisan karet setebal $5 \mathrm{~mm}$. Tiap elevator, minimum menggunakan 4 buffer, tiap buffer dilengkapi dengan Safety Switch yang dihubungkan pada panel kontrol. Panel ini diletakkan pada pondasi beton.

- Guide Rail

Terbuat dari profil baja $T$, rail harus dilapisi dengan suatu bahan pondasi beton.

- Counter Weight
Rangka counter weight terbuat dari profil baja, isi harus seberat kereta elevator ditambah $50 \%$ kapasitas kereta yang terbuat dari besi cor.

- Operating Panel

Terbuat dari dua panel yang terletak pada kedua sisi pintu kereta. Push button merupakan rangkaian elektronik yang dilengkapi dengan lampu indikator dan sebagainya.

- EMR (Elevator Machine Room)

- Untuk sistem elevator elektrik, mesin ditempatkan di atas.

- Untuk sistem elevator hidrolik, mesin diletakkan di bawah.

- Penentuan letak mesin berdasarkan atas struktural dan kemudahan.

\section{Tata Ruang Letak Lift}

Tata ruang letak lift di rumah sakit sering ditentukan dari jumlah dan konfigurasi tata letak lift dan jumlah maksimal empat buah dalam satu deretan.

Untuk bangunan yang tingginya lebih dari 25 lantai, dianjurkan untuk membagi layanan lift dengan mengelompokan lantai yang dilayani/konsep zona, di mana tiap zona dilayani oleh sejumlah lift tertentu. Gambar dibawah ini menunjukkan tata letak sekelompok lift yang baik, alternatif lain dapat juga dilakukan.

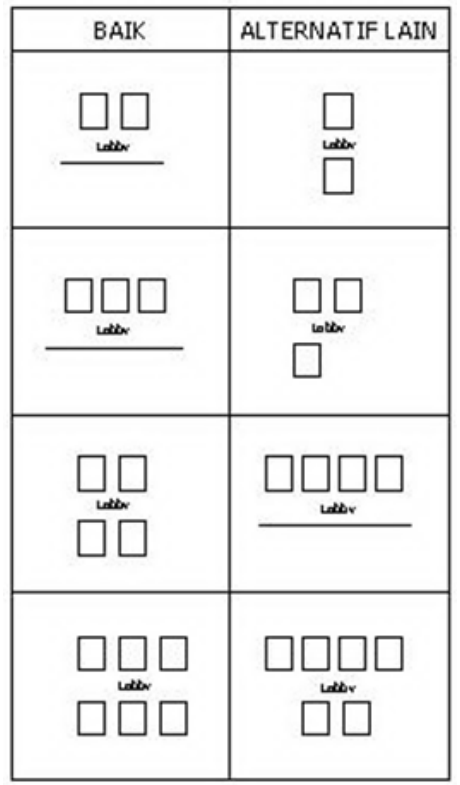

Gambar 1. Tata letak sekelompok lift Sumber: Juwana, 2009 
Pada bangunan tinggi dan luas, jumlah lift yang di perlukan meningkat sebanding dengan jumlah lantai yang dilayani.dengan demikian, jika mencapai suatu ketinggian tertentu, maka areal luas yang digunakan untuk menempatkan lift menjadi meningkat dan melebihi ketentuan ekonomis (di atas 20 $\%$ luas lantai). Jadi pada umumnya lift hanya melayani 12 - 15 lantai.

\section{Macam macam Hydraulic lift}

- Lift hidrolik konvensional pertama kali dikembangkan oleh Dover (sekarang Thyssen Krupp) Elevator. Mereka menggunakan silinder bawah tanah, sangat umum untuk bangunan tingkat rendah dengan 2-7 lantai, dan memiliki kecepatan hingga 200 kaki / menit (1 meter / detik).

- Lift hidrolik Holeless dikembangkan oleh Otis. Elevator pada 1970-an, dan menggunakan sepasang silinder di atas tanah, yang membuatnya praktis untuk lingkungan atau biaya gedung-gedung sensitif dengan 2,3 , atau 4 lantai.

- Lift hidrolik bertali menggunakan kedua alternatif selinder di atas tanah dan sistem tali, yang menggabungkan fleksi-bilitas dari hidrolik dengan keandalan holeless hidrolik, meskipun mereka dapat melayani hingga 8-10 lantai

\section{Jenis - jenis lift penumpang}

Lift penumpang khusus dipergunakan untuk layanan yang mereka lakukan, termasuk: Rumah Sakit. Pintu masuk depan dan belakang, double decker, dan penggunaan lainnya.

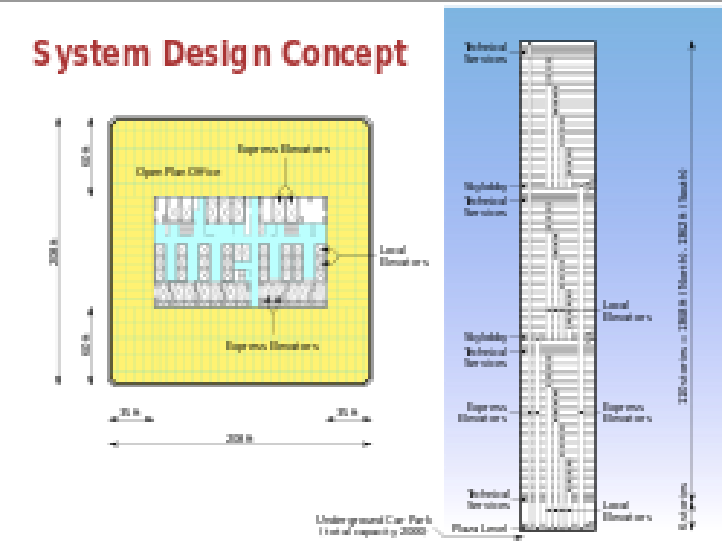

Gambar 2. Sistem konsep lift Sumber: google.com, 2009
Fasilitas Elevator

Fasilitas elevator terdiri dari :

\section{Mesin Room}

Semua lift, baik traksi atau hidrolik, memerlukan ruang untuk menyimpan mesin motor listrik besar (atau pompa hidrolik) dan controller kabinet. Ruangan ini terletak di atas hoistway (atau di bawah, untuk hidrolik lift) dan mungkin berisi mesin untuk satu atau sekelompok lift.

\section{Pintu elevator}

Pintu lift melindungi pengendara dari jatuh ke dalam lubang. Konfigurasi yang paling umum adalah memiliki dua panel yang bertemu di tengah, lalu geser terbuka lateral. Dalam konfigurasi cascading (berpotensi memungkinkan entryways lebih luas dalam ruang terbatas), pintu-pintu dijalankan pada rel independen, sehingga saat terbuka, mereka terselip di belakang satu sama lain, dan ketika tertutup, mereka membentuk lapisan mengalir di satu sisi

\section{Kontrol Umum}

Tipikal lift penumpang modern akan memiliki:

- Ruang untuk berdiri, guardrails, bantalan kursi (mewah)

- Unit pendingin udara untuk meningkatkan sirkulasi dan kenyamanan.

- Tombol panggil untuk memilih lantai. Beberapa dari ini menjadi kunci saklar (untuk mengontrol akses). Dalam beberapa lift, lantai tertentu tidak dapat diakses kecuali menggunakan kartu swipes keamanan atau memasukkan kode akses atau keduanya

- Satu set pintu tetap terkunci di setiap lantai untuk mencegah akses yang tidak disengaja ke dalam lift oleh individu .

- Memicu alarm. Sering kali, ini akan menjadi kunci switch.

- Tombol alarm atau switch, dimana penumpangnya dapat digunakan untuk memberi sinyal bahwa mereka telah terjebak di lift.

\section{Kapasitas}

Biasanya lift penumpang tersedia dalam kapasitas dari 450-2700 kg dalam $230 \mathrm{~kg}$ bertahap. Umumnya penumpang lift di bangunan delapan lantai atau kurang menggunakan system hidrolik atau listrik, 
yang dapat mencapai kecepatan hingga $200 \mathrm{ft}$ / $\min (1,0 \mathrm{~m} \mathrm{/} \mathrm{s})$ hidrolik dan sampai $500 \mathrm{ft} /$ min . Pada bangunan sampai dengan sepuluh lantai, gearless cenderung memiliki kecepatan hingga $500 \mathrm{ft} / \min (2,5 \mathrm{~m} / \mathrm{s})$, dan di atas lantai sepuluh kecepatan mulai pada $500 \mathrm{ft} /$ $\min (2,5 \mathrm{~m} / \mathrm{s})$ sampai $2000 \mathrm{ft} / \min (10 \mathrm{~m} / \mathrm{s})$.

\section{Standar Lift untuk penyandang cacat}

Pada bangunan belantai banyak, lift merupakan alat utama untuk sirkulasi vertikal terutama bagi penyandang cacat berkursi roda dan mereka yang sulit untuk berjalan.

Standar ukuran lift untuk kaum cacat:

- Panjang : $110 \mathrm{~cm}$

- Lebar : $90 \mathrm{~cm}$

- Bukaan pintu : $70 \mathrm{~cm}$

Standar ukuran lift untuk kaum cacat yang ditemani:

- Panjang : $140 \mathrm{~cm}$

- Lebar : $110 \mathrm{~cm}$

- Bukaan pintu : $70 \mathrm{~cm}$

Standar ketinggian tombol pengendali dapat ditekan dengan mudah. Untuk penggunaan umum tata letak vertikal dengan jarak tombol $30 \mathrm{~cm}$, tinggi panel rata rata 140 $\mathrm{cm}$ maksimal $160 \mathrm{~cm}$. Sedangkan untuk kaum cacat tanpa pengawal tidak boleh lebih dari $130 \mathrm{~cm}$.

\section{METODE PENELITIAN}

Bahan dan Peralatan penelitian

Peralatan yang dipergunakan meliputi Kamera Alat Tulis, Alat Gambar dan jam.

\section{Pengumpulan data}

Pengambilan data dilakukan dengan cara studi literatur, survey lapangan dengan untuk mengambil data, sketsa dan foto bangunan yang akurat, wawancara / interview quisioner

\section{Analisis dan Sintesis}

Data yang diperoleh di lapangan mengenai kenyamanan Lift akan dianalisis dengan membandingkannya dengan hasil studi literatur. Selanjutnya hasil kuesioner akan dianalisis dan kemudian antara hasil analisis kuesioner dan studi literature akan dibandingkan

\section{Penentuan Parameter (Landasan teori)}

Standar penentuan penerapan sistem Aksesibilitas pada lift ditentukan berdasarkan:
1. Koridor/lobby lift

Ruang perantara untuk menunggu kedatangan lift, sekaligus mewadahi penumpang yang baru keluar dari lift harus disediakan lebar ruangan ini minimal 185 $\mathrm{cm}$ dan tergantung konfigurasi ruang .

2. Kontrol umum

a. Perletakan tombol dan layar tampilan yang mudah di lihat dan mudah dijangkau.

b. Panel luar yang berisikan tombol lift harus di pasang di tengah lobby atau hall lift dengan ketinggian 90-110 cm dari muka lantai bangunan.

c. Panel dalam dari lift di pasang dengan ketinggian $90-110 \mathrm{~cm}$ dari lantai ruang lift

d. Semua tombol harus memakai huruf braile yang di pasang dengan atau tanpa mengganggu tombol biasa lift.

e. Selain terdapat indikator suara, layar/ tampilan yang secara visual menunjukan posisi lift harus dipasang diatas pintu lift baik di dalam maupun di luar lift.

3. Ruang lift/Elevator

a. Ukuran ruang harus dapat memuat pengguna kursi roda, mulai dari masuk melewati pintu lift, gerakan memutar, menjangkau panel tombol dan keluar melewati pintu lift. Ukuran bersih minimal ruang lift adalah $140 \mathrm{~cm} \times 140$ $\mathrm{cm}$.

b. Ruang lift harus di lengkapi pegangan rambat pada ketiga sisinya.

4. Pintu lift

a. Waktu minimum bagi pintu untuk tetap terbuka karena menjawab panggilan adalah 3 detik. Sedangkan Ukuran bersih minimal pintu lift adalah $110 \mathrm{~cm}$.

b. Mekanisme pembukaan dan penutupan pintu harus sedemikian rupa sehingga memberikan waktu yang cukup bagi pengguna untuk keluar masuk.

c. Penyandang cacat terutama untuk masuk dan keluar dengan mudah. Untuk itu lift dilengkapi oleh sensor photo elektrik yang dipasang pada ketinggian yang sesuai.

Metode penelitian dapat dilukiskan secara diagramatis dengan bagan proses penelitian sebagai berikut : 


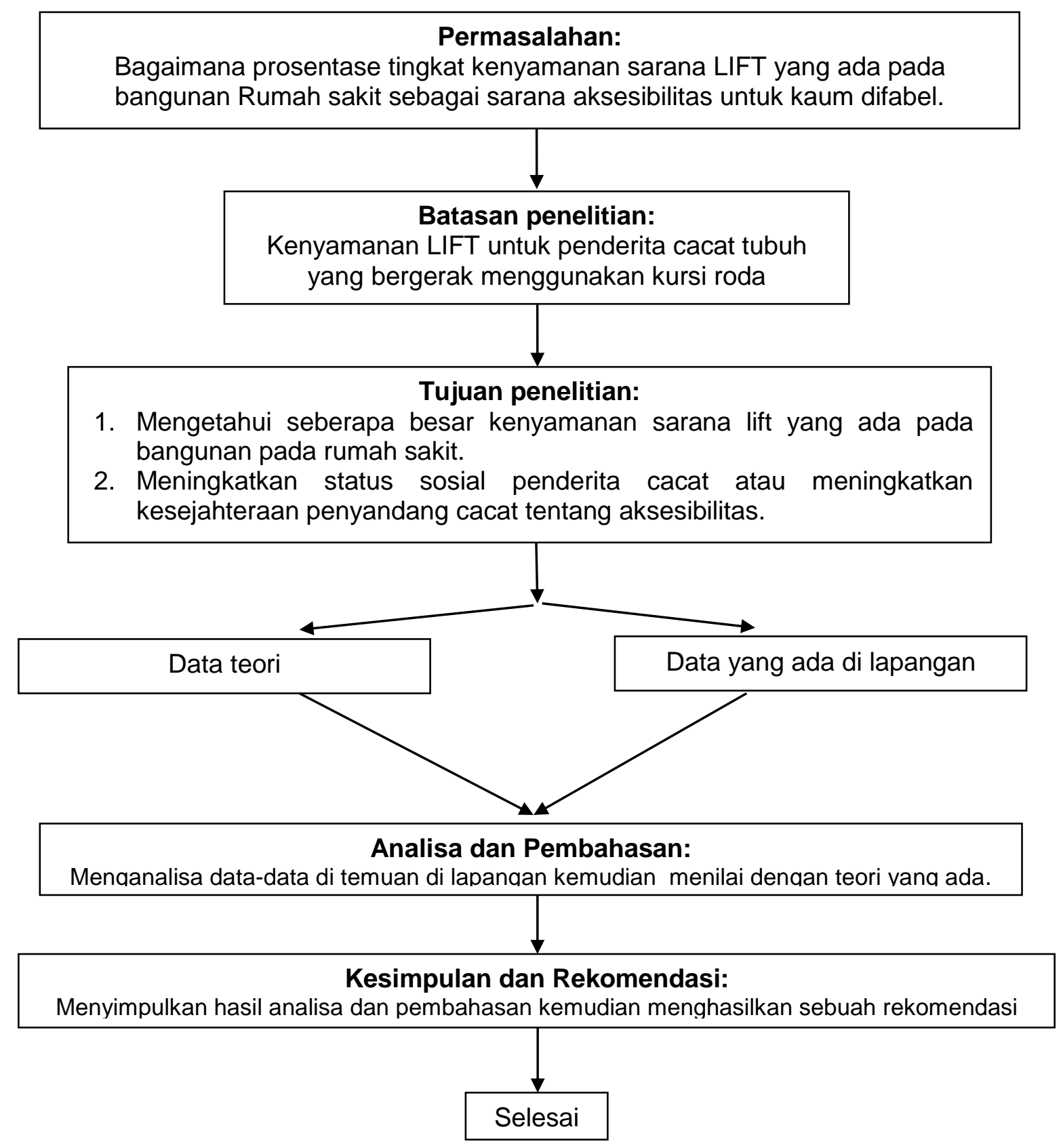

Gambar 3. Bagan alir penelitian Sumber: Peneliti 2010

\section{DISKRIPSI OBYEK PENELITIAN}

Kota Solo terletak sekitar $65 \mathrm{~km}$ Timur Laut Yogyakarta dan $100 \mathrm{~km}$ Tenggara. Semarang. Lokasi kota ini berada di dataran rendah (hampir 100m di atas permukaan laut) yang diapit Gunung Merapi di Barat dan Gunung Lawu di Timur. Agak jauh di selatan terbentang Pegunungan Sewu. Di sebelah Timur mengalir Bengawan Solo dan di bagian Utara mengalir Kali Pepe yang merupakan bagian dari Daerah Aliran Sungai Solo.

Tinjauan lokasi penelitian ini dilakungan pada rumah sakit di Surakarta yang khususnya bangunan rumah sakit bertingkat yang memiliki memiliki mobilitas berupa lift(elevator). Tiga rumah sakit ini adalah Rumah Sakit Kasih Ibu, Rumah Sakit Islam Yarsis dan Rumah Sakit Moewardi. 


\section{HASIL DAN PEMBAHASAN}

Data hasil amatan di lapangan terdiri dari 3 kasus yaitu:

\section{Kasus 1 : Rumah Sakit Kasih Ibu}

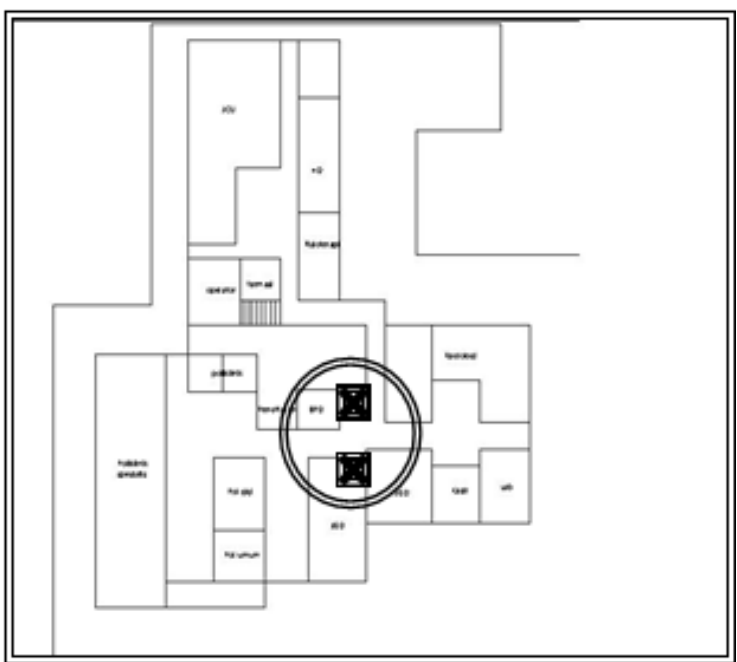

Gambar 4. Letak lift RS. Kasih Ibu

Sumber: Survey Lapangan, 2010

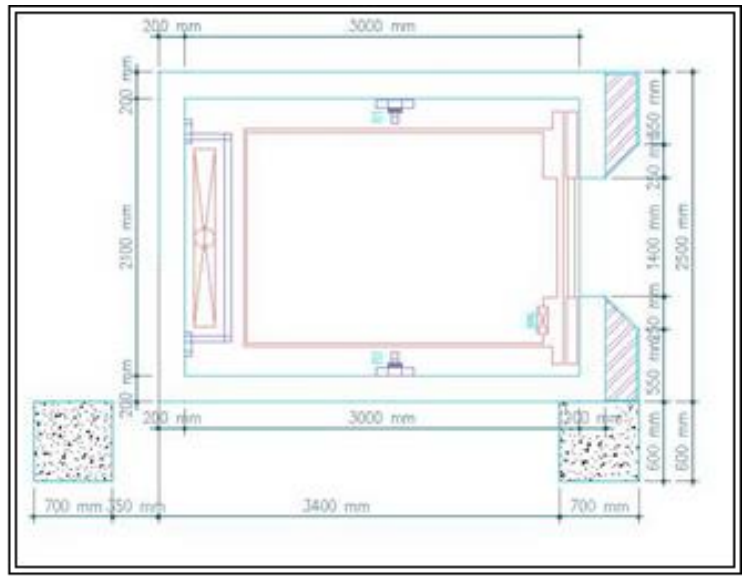

Gambar 5. Detail lift RS. Kasih Ibu

Sumber: Survey Lapangan, 2010

\section{Kondisi fisik lift (elevator)}

Kondisi fisik lift (elevator) di rumah sakit Kasih lbu antara lain :

1. Lift di rumah sakit Kasih lbu berpola berhadapan. Dan lobby berada ditengah lift.

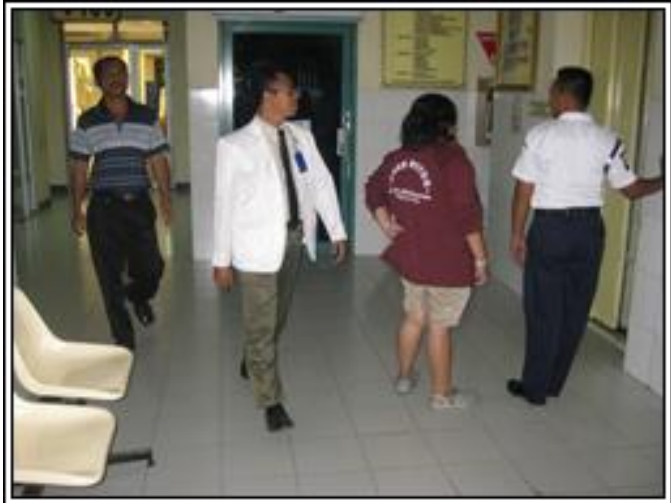

Gambar 6. Lobby lift RS. Kasih Ibu

Sumber: Survey Lapangan, 2009

2. Pada lift luasan ruang Ukuran bersih ruang lift adalah $140 \mathrm{~cm}$ x $180 \mathrm{~cm}$.

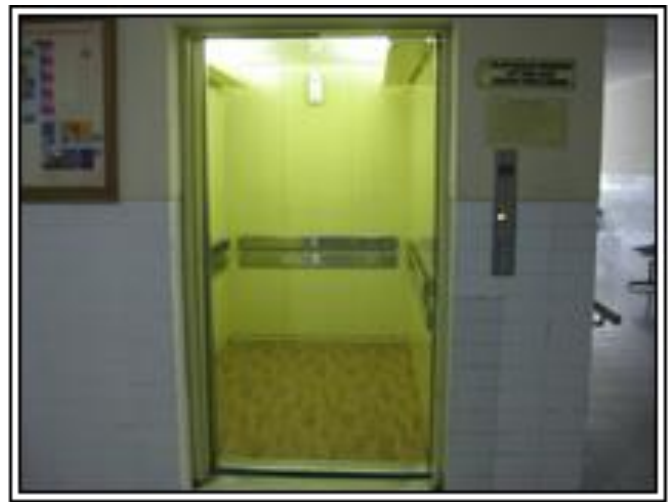

Gambar 7. Ruang lift RS. Kasih Ibu Sumber: Survey Lapangan, 2009

3. Pada ruang lift di lengkapi handle atau pegangan rambat pada ketiga sisinya.

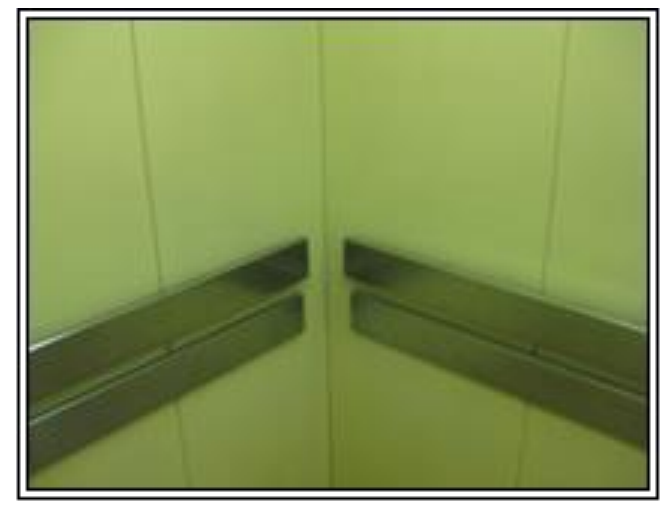

Gambar 8. Pegangan handle lift Sumber: Survey Lapangan, 2009 
4. Perletakan tombol dan layar tampilan yang mudah di lihat dan mudah dijangkau, dengan ketinggian $90 \mathrm{~cm}$ dari muka lantai bangunan.

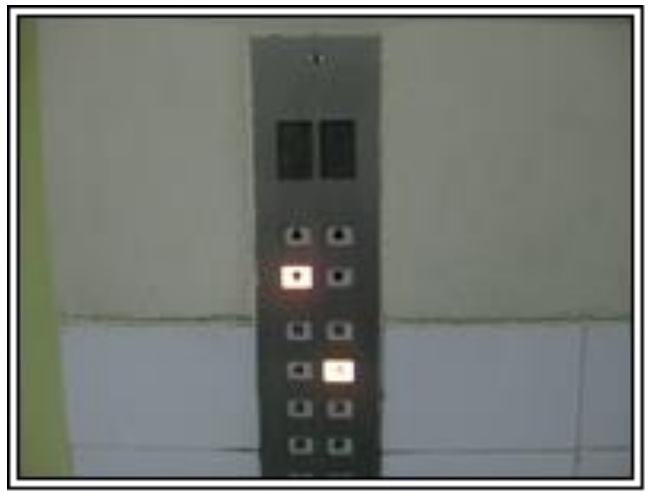

Gambar 9. Tata letak tombol lift Sumber: Survey Lapangan, 2009

\section{Kasus 2 : Rumah Sakit Islam Yarsis}

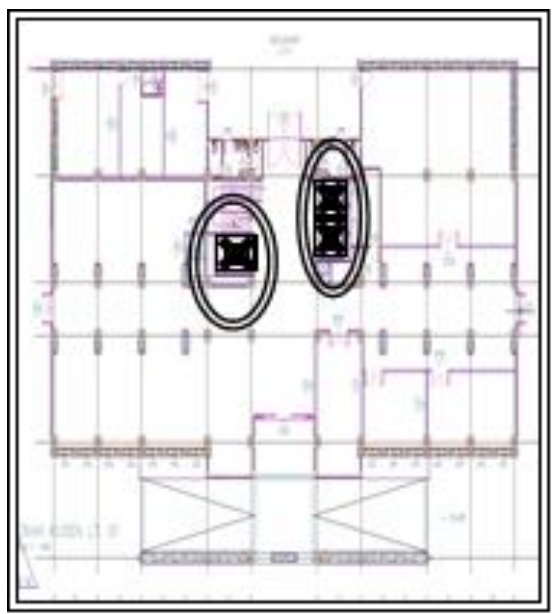

Gambar 10. Letak lift rumah sakit Yarsis Sumber: Survey Lapangan, 2010

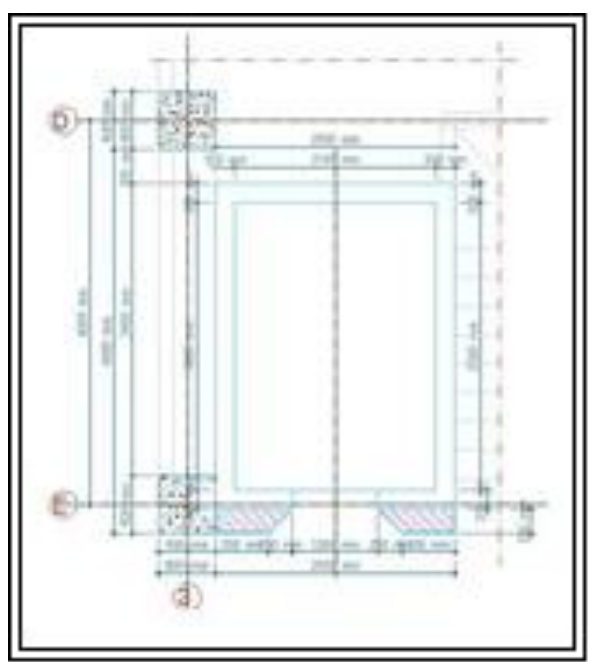

Gambar 11. Detail lift RS. Yarsis Sumber: Survey Lapangan, 2010

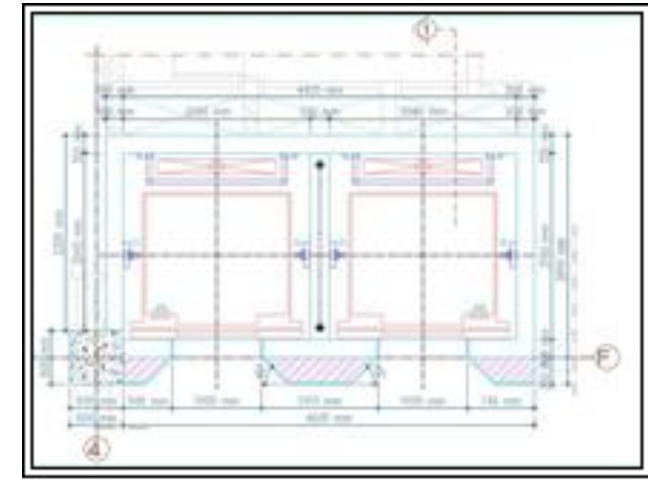

Gambar 12. Detail lift RS. Yarsis Sumber: Survey Lapangan, 2010

\section{Kondisi fisik lift (elevator)}

Kondisi fisik lift (elevator) di rumah sakit Islam Yarsis

1. Lobby lift pada rumah sakit yarsis sangat luas ukuran $5 \times 5 \mathrm{~m}$.

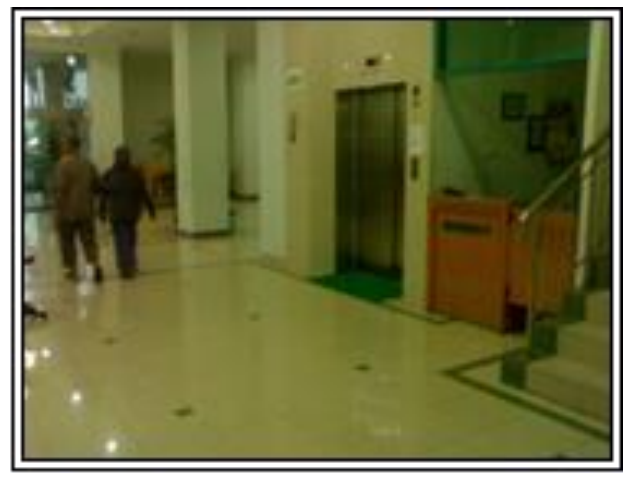

Gambar 13. Lobby lift RS. Yarsis Sumber: Survey Lapangan, 2009

2. Ukuran bersih ruang lift adalah $210 \mathrm{~cm} x$ $300 \mathrm{~cm}$. Ruangan lift ini memungkinkan untuk memutar kursi roda.
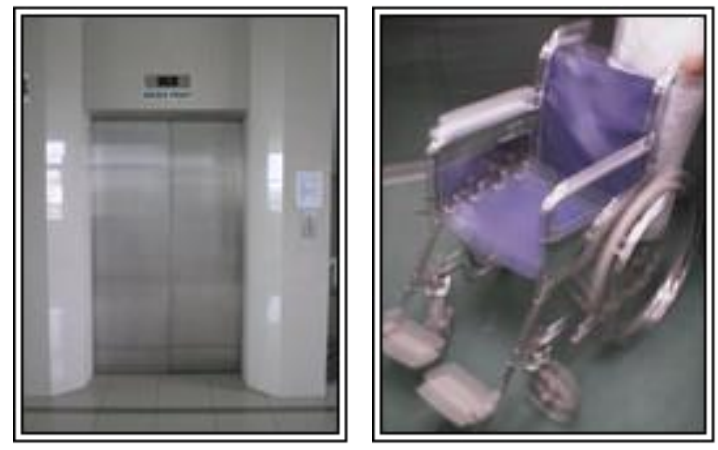

Gambar 14. Ruang lift RS. Yarsis

Sumber: Survey Lapangan, 2009 
3. Pada ruang lift di rumah sakit yarsis juga dilengkapi handle atau pegangan rambat pada ketiga sisinya.

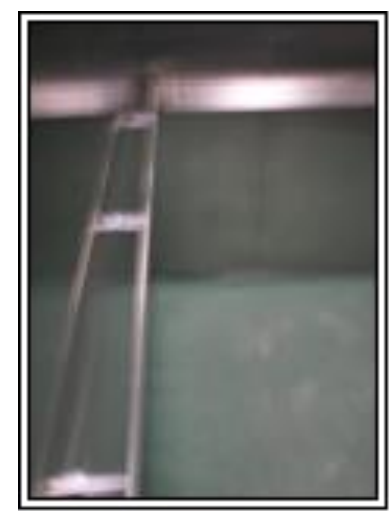

Gambar 15. Pegangan lift RS. Yarsis

Sumber: Survey Lapangan, 2009

4. Perletakan tombol dan layar tampilan mudah di lihat dan mudah dijangkau, dengan ketinggian $100 \mathrm{~cm}$ dari muka lantai bangunan. Maka terjadi kenyamanan untuk menekan tombol.

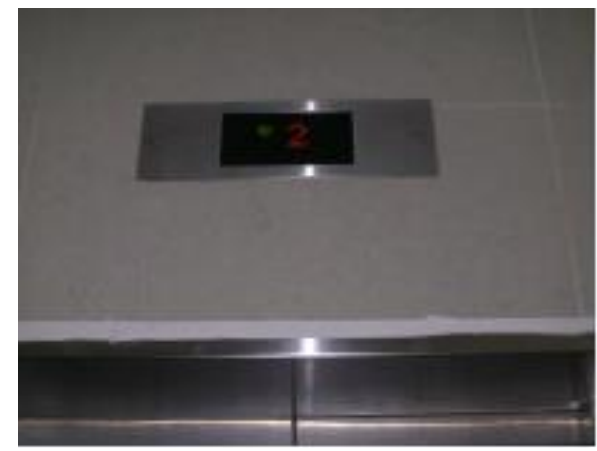

Gambar 16. Tata letak tombol lift Sumber: Survey Lapangan, 2009

\section{Kasus 3 : Rumah Sakit Islam Moewardi}

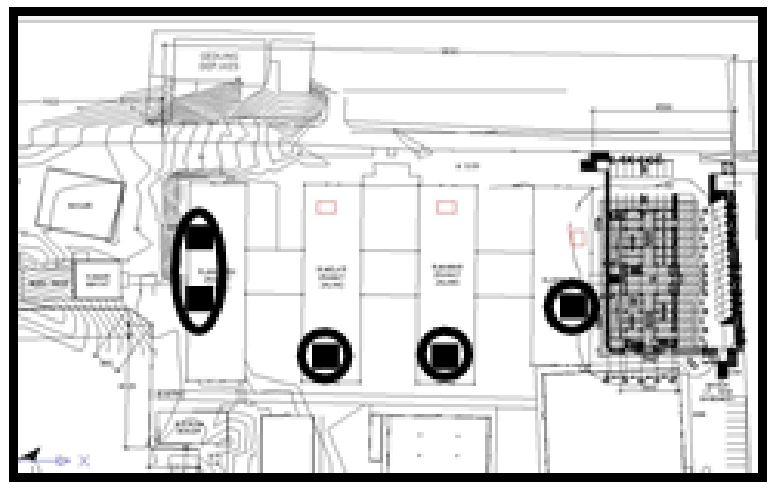

Gambar 17. Letak lift RS. Moewardi

Sumber: Survey Lapangan, 2010
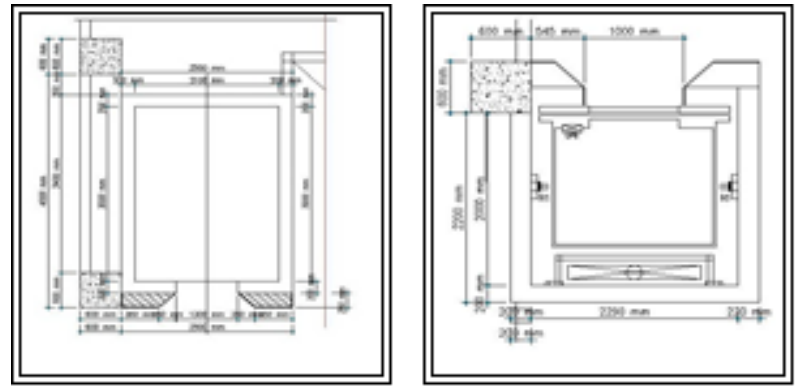

Gambar 18. Detail lift RS. Moewardi Sumber: Survey Lapangan, 2010

\section{Kondisi fisik lift (elevator)}

Kondisi fisik lift (elevator) di rumah sakit Moewardi adalah :

1. Lobby rumah sakit moewardi sudah cukup nyaman untuk sirkulasi

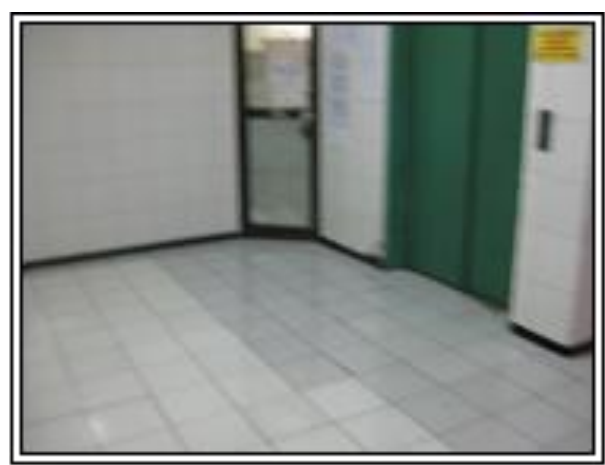

Gambar 19. Kondisi lobby lift RS. Moewardi Sumber: Survey Lapangan, 2009

2. Ukuran bersih ruang lift adalah $140 \mathrm{~cm} x$ $210 \mathrm{~cm}$. Ruangan lift ini tidak memungkinkan untuk memutar kursi roda dengan baik.
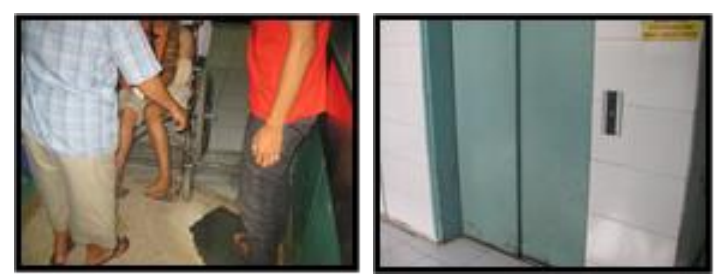

Gambar 20. Luas Ruang lift RS. Moewardi Sumber: Survey Lapangan, 2009

3. Pada ruang lift juga tidak dilengkapi handle atau pegangan rambat pada ketiga sisinya 


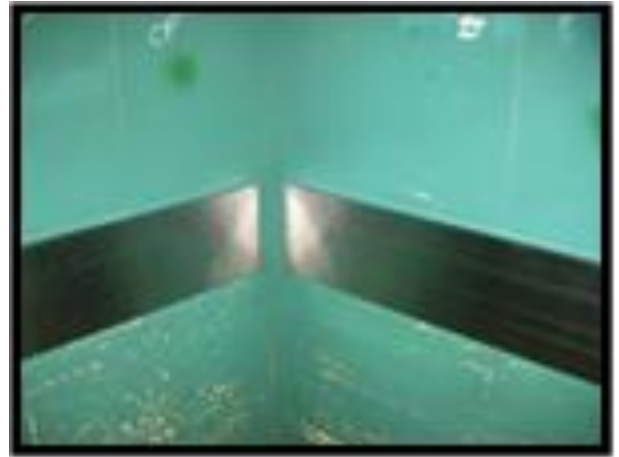

Gambar 21. Handle lift RS. Moewardi Sumber: Survey Lapangan, 2009

4. Tombol dapat dilihat dan mudah dijangkau, dengan ketinggian $100 \mathrm{~cm}$ dari muka lantai bangunan.

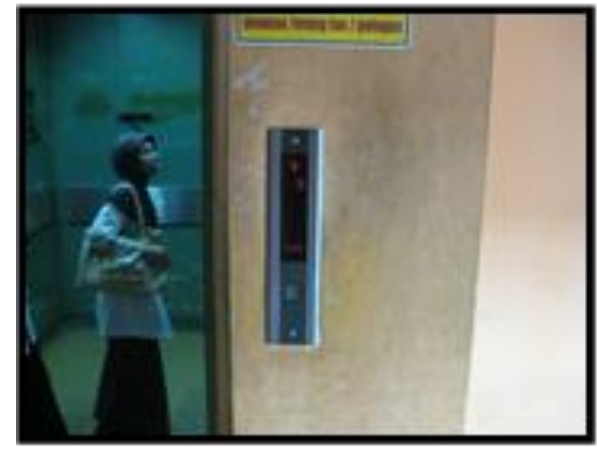

Gambar 22. Tata letak tombol lift Sumber: Survey Lapangan, 2009

Berdasarkan data tersebut diatas, selanjutnya diadakan analisis dengan menggunakan parameter koridoor (lobby lift), Kontrol umum, ruang lift dan pintu lift.

\section{Analisis Kondisi Lift}

Tabel 1. Analisa lift di ketiga rumah sakit

\begin{tabular}{|c|c|c|c|c|}
\hline No & $\begin{array}{l}\text { Rumah } \\
\text { sakit }\end{array}$ & $\begin{array}{l}\text { Para } \\
\text { meter }\end{array}$ & $\begin{array}{l}\text { Hasil } \\
\text { Temuan } \\
\text { Lapangan }\end{array}$ & Ket. \\
\hline \multirow[t]{2}{*}{01} & \multirow[t]{2}{*}{$\begin{array}{l}\text { RS } \\
\text { Kasih } \\
\text { Ibu }\end{array}$} & $\begin{array}{l}\text { Loby lift } \\
(185 \times 185)\end{array}$ & $\begin{array}{l}\text { Posisi } \\
\text { lobby di } \\
\text { tengah lift } \\
\text { serta } \\
\text { berukuran } \\
3 \times 3 \text { m }\end{array}$ & $\begin{array}{l}\text { Masuk } \\
\text { kriteria } \\
\text { stándar }\end{array}$ \\
\hline & & $\begin{array}{l}\text { Panel } \\
\text { Tombol } \\
\text { luar tinggi } \\
90-120 \\
m\end{array}$ & $\begin{array}{l}\text { Ketinggian } \\
90 \mathrm{~cm} \text { dari } \\
\text { muka } \\
\text { lantai } \\
\text { bangunan. }\end{array}$ & $\begin{array}{l}\text { Masuk } \\
\text { kriteria } \\
\text { standar }\end{array}$ \\
\hline
\end{tabular}

\begin{tabular}{|c|c|c|c|c|}
\hline & & $\begin{array}{l}\text { Pegangan } \\
\text { lift }\end{array}$ & $\begin{array}{l}\text { Ketiga sisi } \\
\text { lift } \\
\text { mempuny } \\
\text { ai } \\
\text { pegangan } \\
\text { rambat }\end{array}$ & $\begin{array}{l}\text { Masuk } \\
\text { kriteria } \\
\text { standar }\end{array}$ \\
\hline & & $\begin{array}{l}\text { Posisi lift } \\
\text { pada lantai }\end{array}$ & $\begin{array}{l}\text { Tidak ada } \\
\text { tampilan } \\
\text { posisi lift } \\
\text { pada atas } \\
\text { lift }\end{array}$ & $\begin{array}{l}\text { Kurang } \\
\text { masuk } \\
\text { kriteria } \\
\text { standar }\end{array}$ \\
\hline & & $\begin{array}{l}\text { Ukuran } \\
\text { ruang lift }\end{array}$ & $\begin{array}{l}\text { Ukuran } \\
\text { bersih } \\
\text { ruang lift } \\
\text { adalah } \\
210 \mathrm{~cm} x \\
300 \mathrm{~cm} .\end{array}$ & $\begin{array}{l}\text { Masuk } \\
\text { kriteria } \\
\text { standar }\end{array}$ \\
\hline & & $\begin{array}{l}\text { Luas pintu } \\
\text { lift }\end{array}$ & $\begin{array}{l}\text { Luas pintu } \\
\text { lift } \\
\text { berukuran } \\
140 \mathrm{~cm}\end{array}$ & $\begin{array}{l}\text { Masuk } \\
\text { kriteria } \\
\text { standar }\end{array}$ \\
\hline 02 & $\begin{array}{l}\text { RS } \\
\text { Islam } \\
\text { Yarsis }\end{array}$ & $\begin{array}{l}\text { Loby lift } \\
(185 \times 185)\end{array}$ & $\begin{array}{l}\text { Posisi } \\
\text { lobby di } \\
\text { tengah lift } \\
\text { serta } \\
\text { berukuran } \\
3 \times 3 \mathrm{~m}\end{array}$ & $\begin{array}{l}\text { Masuk } \\
\text { kriteria } \\
\text { standar }\end{array}$ \\
\hline & & $\begin{array}{l}\text { Panel } \\
\text { Tombol } \\
\text { luar tinggi } \\
90-120 \\
\text { m }\end{array}$ & $\begin{array}{l}\text { ketinggian } \\
100 \mathrm{~cm} \\
\text { dari muka } \\
\text { lantai } \\
\text { bangunan. }\end{array}$ & $\begin{array}{l}\text { Masuk } \\
\text { kriteria } \\
\text { standar }\end{array}$ \\
\hline & & $\begin{array}{l}\text { Pegangan } \\
\text { lift }\end{array}$ & $\begin{array}{l}\text { Ketiga sisi } \\
\text { lift } \\
\text { mempuny } \\
\text { ai } \\
\text { pegangan } \\
\text { rambat }\end{array}$ & $\begin{array}{l}\text { Masuk } \\
\text { kriteria } \\
\text { standar }\end{array}$ \\
\hline & & $\begin{array}{l}\text { Posisi lift } \\
\text { pada lantai }\end{array}$ & $\begin{array}{l}\text { Ada } \\
\text { tampilan } \\
\text { posisi lift } \\
\text { pada atas } \\
\text { lift }\end{array}$ & $\begin{array}{l}\text { Masuk } \\
\text { kriteria } \\
\text { standar }\end{array}$ \\
\hline & & $\begin{array}{l}\text { Ukuran } \\
\text { ruang lift }\end{array}$ & $\begin{array}{l}\text { Ukuran } \\
\text { bersih } \\
\text { ruang lift } \\
\text { adalah } \\
210 \mathrm{~cm} \times \\
300 \mathrm{~cm} .\end{array}$ & $\begin{array}{l}\text { Masuk } \\
\text { kriteria } \\
\text { standar }\end{array}$ \\
\hline & & $\begin{array}{l}\text { Luas pintu } \\
\text { lift }\end{array}$ & $\begin{array}{l}\text { Luas pintu } \\
\text { lift } \\
\text { berukuran } \\
140 \mathrm{~cm}\end{array}$ & $\begin{array}{l}\text { Masuk } \\
\text { kriteria } \\
\text { standar }\end{array}$ \\
\hline 03 & $\begin{array}{l}\text { RS Moe } \\
\text { wardi }\end{array}$ & $\begin{array}{l}\text { Loby lift } \\
(185 \times 185)\end{array}$ & $\begin{array}{l}\text { Posisi } \\
\text { lobby di } \\
\text { tengah lift } \\
\text { serta } \\
\text { berukuran } \\
3 \times 3 \mathrm{~m}\end{array}$ & $\begin{array}{l}\text { Masuk } \\
\text { kriteria } \\
\text { standar }\end{array}$ \\
\hline
\end{tabular}




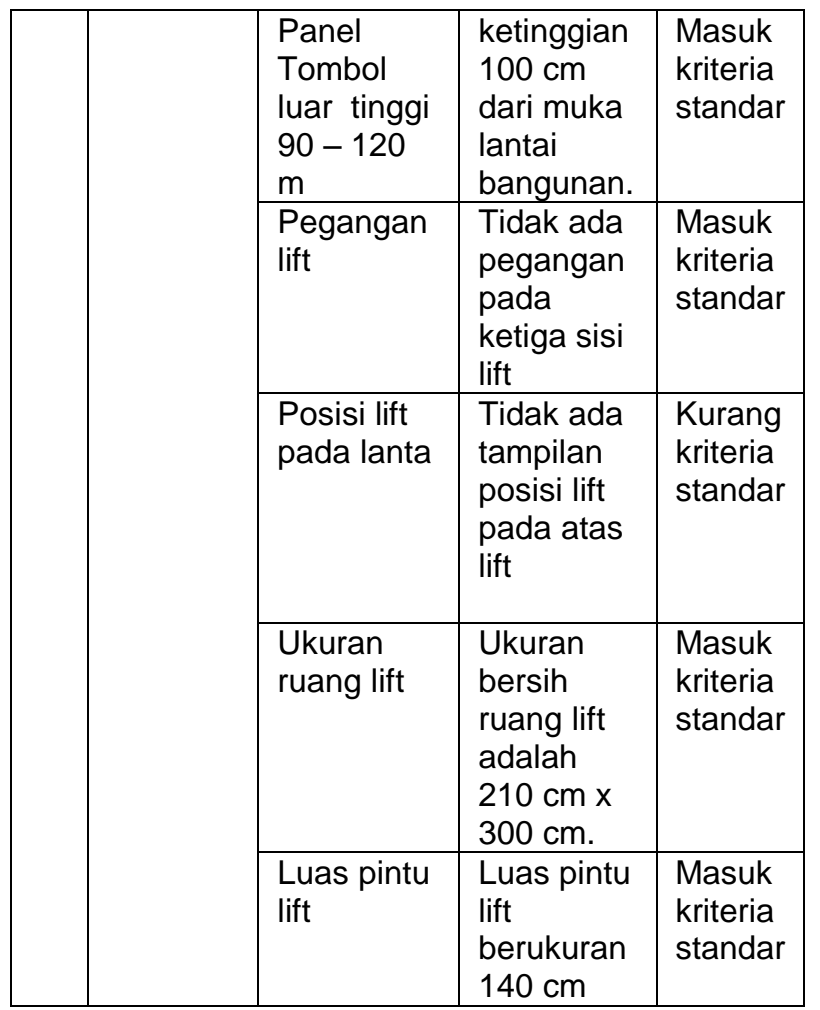

Sumber : Analisis 2010

\section{Hasil survey quisioner.}

Untuk mengetahui tingkat kenyamanan pada lift (elevator) di rumah sakit dilakukan dengan menyebarkan quisioner pada penderita cacat di ketiga rumah sakit yang dijadikan lokasi penelitian

\section{Analisa Data}

\section{Distribusi Frekuensi}

Berdasarkan survey, terdapat 5 pertanyaan yang harus dijawab responden. Responden adalah para penyandang cacat dan berjumlah 30 orang. Dari 5 pertanyaan tersebut, maka terdapat 5 perhitungan yang menghasilkan 5 tabel frekuensi. Hasil perhitungan tersebut adalah sebagai berikut:

1) Frekuensi keperluan berada di rumah sakit

Tabel 2. Frekuensi Keperluan di Rumah Sakit

\begin{tabular}{|c|l|c|}
\hline No & Responden & Frekuensi \\
\hline 1 & Berkunjung & 11 \\
\hline 2 & Dirawat & 19 \\
\hline 3 & Lain-lain & - \\
\hline & Jumlah Total & 30 \\
\hline
\end{tabular}

Sumber: Hasil Survey Tahun 2010

\section{2) Frekuensi penggunaan alat}

Tabel 3. Frekuensi penggunaan alat

\begin{tabular}{|c|l|c|}
\hline No & Responden & Frekuensi \\
\hline 1 & Lift & 29 \\
\hline 2 & Ramp & 1 \\
\hline 3 & Lain-lain & - \\
\hline & Jumlah Total & 30 \\
\hline
\end{tabular}

Sumber: Hasil survei Tahun 2010

\section{3) Frekuensi kenyamanan letak lift}

Tabel 4. Frekuensi kenyamanan letak lift

\begin{tabular}{|c|l|c|}
\hline No & Responden & Frekuensi \\
\hline 1 & Sudah & 5 \\
\hline 2 & Cukup & 17 \\
\hline 3 & Belum & 7 \\
\hline & Jumlah Total & 29 \\
\hline
\end{tabular}

Sumber: Hasil Survei Tahun 2010

\section{4) Frekuensi kenyamanan lift}

Tabel 5. Frekuensi kenyamanan lift

\begin{tabular}{|c|l|c|}
\hline No & Responden & Frekuensi \\
\hline 1 & Cukup & 13 \\
\hline 2 & Kurang & 16 \\
\hline 3 & Belum & - \\
\hline & Jumlah Total & 29 \\
\hline
\end{tabular}

Sumber: Hasil Survei 2010

5) Frekuensi bagian yang kurang nyaman

Tabel 6. Frekuensi bagian yang kurang nyaman

\begin{tabular}{|c|l|c|}
\hline No & Responden & Frekuensi \\
\hline 1 & Luasan & 2 \\
\hline 2 & Pegangan & 7 \\
\hline 3 & Lebar pintu & 2 \\
\hline 4 & Tombol pintu & 4 \\
\hline 5 & Lain-lain & 3 \\
\hline & Jumlah Total & 18 \\
\hline
\end{tabular}

Sumber: Hasil Survei tahun 2010

\section{Ukuran Tendensi Pusat}

Ukuran tendensi pusat adalah nilai-nilai yang mewakili seluruh anggota di dalam kelompok sampel. Biasanya nilai yang dipakai untuk tendensi pusat yaitu nilai yang tertinggi. Jadi, ukuran tendensi pusat pada pertanyaan responden diatas adalah sebagai berikut: 
1) Pada frekuensi pengunjung rumah sakit, ukuran tendensi pusatnya adalah 19 responden yang menjawab dirawat sebagai pasien sebesar (63.33\%).

2) Pada frekuensi penggunaan alat transportasi vertikal, ukuran tendensi pusatnya adalah 29, responden yang menjawab menggunakan lift $(96,6 \%)$.

3) Pada frekuensi kenyamanan letak lift, ukuran tendensi pusatnya adalah 17 responden yang menjawab cukup nyaman $(58,6 \%)$.

4) Pada frekuensi kenyamanan lift, ukuran tendensi pusatnya adalah 16 responden yang menjawab kurang nyaman $(55,17 \%)$.

5) Pada frekuensi bagian lift yang kurang nyaman pada pegangan lift, untuk tendensi pusatnya adalah 7 responden yang menjawab Pegangan pada lift (38,88 \%).

\section{Ukuran Dispersi}

Ukuran tendensi pusat selalu di sertai dengan ukuran dispersi yang menunjukkan variasi di dalam kelompok sampel. Ukuran dispersinya adalah Indeks Variabel Komulatif (IVK) dapat dihitung dengan rumus di bawah ini:

$$
I V K=\frac{\sum n_{i} \cdot n_{j}}{p\left(\frac{n}{k}\right)^{2}} \times 100 \%
$$

Keterangan:

$\mathrm{n}_{\mathrm{i}}$ : jumlah frekuensi kategori tertentu

$n_{j}$ : jumlah frekuensi kategori-kategori lain

$p$ : jumlah pasangan $n_{i}$ dan $n_{j}$

$\mathrm{n}$ : jumlah seluruh frekuensi

$\mathrm{k}$ : banyaknya kategori

Dengan menggunakan rumus diatas, hasilnya adalah sebagai berikut:

1) Pada frekuensi pengunjung rumah sakit, ukuran tendensi pusatnya adalah 19 responden yang menjawab dirawat sebagai pasien maka ukuran dispersinya adalah $69,7 \%$

2) Pada frekuensi penggunaan alat transportasi vertikal, ukuran tendensi pusatnya adalah 29 , responden yang menjawab menggunakan lift $(96,6 \%)$.

3) Pada frekuensi kenyamanan letak lift, ukuran tendensi pusatnya adalah 17 responden yang menjawab cukup nyaman maka ukuran dispersinya adalah $84,6 \%$.

4) Pada frekuensi kenyamanan lift, ukuran tendensi pusatnya adalah 16 responden yang menjawab kurang nyaman maka ukuran dispersinya adalah $73,7 \%$

5) Pada frekuensi bagian lift yang kurang nyaman pada pegangan lift, untuk tendensi pusatnya adalah 7 responden yang menjawab pegangan pada lift, maka ukuran dispersinya adalah $93,4 \%$.

\section{Estimasi Parameter}

Modus adalah statistik, karena merupakan salah satu ukuran pada sampel. Semua ukuran yang dipakai pada sampel disebut statistik. Kalau ukuran tersebut dipakai pada populasi, maka namanya bukan statistic tetapi parameter.

Bila parameter ditulis dengan $p$, maka $p$ perlu diestimasi berdasarkan statistik $p$. Estimasi proporsi itu dihitung dengan rumus:

$$
\left(p-Z_{a} / 2: n-1 . \sigma_{p}\right) \leq p \leq\left(p-z_{\left.a / 2: n-1 . \sigma_{p}\right)}\right.
$$

Keterangan:

Za/2:n-1 : Batas konfidensi $(1,96)$.

$\mathrm{P} \quad$ : Statistik proporsi.

$\sigma_{\mathrm{p}} \quad$ : Standar eror distribusi sampling proporsi, dapat dihitung dengan rumus :

$$
\sigma_{p}=\sqrt{\frac{p(1-P)}{n}}
$$

Dengan menggunakan rumus diatas, dihasilkan angka sebagai berikut :

1) Pada frekuensi pengunjung rumah sakit, ukuran tendensi pusatnya adalah 19 responden yang menjawab dirawat sebagai pasien sebesar (63.33\%).

Jadi frekuensi pengunjung rumah sakit pada populasi berada di antara 0,4628 $(46,28 \%)$ ke $0,803(80,3 \%)$ pada tingkat konfidensi $95 \%$.

2) Pada frekuensi penggunaan alat transportasi vertikal, ukuran tendensi pusatnya adalah 29, responden yang menjawab menggunakan lift $(96,6 \%)$.

Jadi frekuensi penggunaan alat transportasi vertikal di rumah sakit pada 
populasi berada di antara $0,901(90,1 \%)$ ke $1,030(103 \%)$ pada tingkat konfidensi $95 \%$.

3) Pada frekuensi kenyamanan letak lift, ukuran tendensi pusatnya adalah 17 responden yang menjawab cukup nyaman $(58,6 \%)$.

Jadi frekuensi kenyamanan letak lift tersebut pada populasi berada di antara $0,407(40,7 \%)$ ke $0,764(76,4 \%)$ pada tingkat konfidensi $95 \%$.

4) Pada frekuensi kenyamanan lift, ukuran tendensi pusatnya adalah 16 responden yang menjawab kurang nyaman $(55,17 \%)$. Jadi frekuensi kenyamanan lift di rumah sakit pada populasi berada di antara 0,371 $(37,1 \%)$ ke $0,732(73,2 \%)$ pada tingkat konfidensi $95 \%$.

5) Pada frekuensi bagian lift yang kurang nyaman pada pegangan lift, untuk tendensi pusatnya adalah 7 responden yang menjawab Pegangan pada lift $(38,88 \%)$.

Jadi frekuensi bagian lift yang kurang nyaman di rumah sakit pada populasi berada di antara 0,1638 (16,38\%) ke $0,6138(61,38 \%)$ pada tingkat konfidensi $95 \%$.

\section{Temuan - temuan.}

1. Tata letak lift pada ketiga rumah sakit yang dijumpai di lapangan sudah cukup baik sedangkan pada frekuensi kenyamanan letak lift, ukuran tendensi pusatnya adalah 17 responden yang menjawab cukup nyaman $(58,6 \%)$. Frekuensi kenyamanan letak lift tersebut pada populasi berada di antara $0,407(40,7 \%)$ ke $0,764(76,4 \%)$ pada tingkat konfidensi $95 \%$. Sehingga data yang ada di lapangan dan data quisioner benar.

2. Perbandingan luas pintu lift yang ada di ketiga rumah sakit adalah $140 \mathrm{~cm}$ dengan data parameter standar lift sudah cocok. Sehingga luas ruang lift tersebut sudah nyaman.

3. Pada frekuensi kenyamanan lift, ukuran tendensi pusatnya adalah 16 responden yang menjawab kurang nyaman pada pegangan lift $(55,17 \%)$. Frekuensi bagian lift yang kurang nyaman di rumah sakit pada populasi berada di antara 0,1638 $(16,38 \%)$ ke 0,6138 (61,38 \%) pada tingkat konfidensi $95 \%$, sedangkan data yang ada dari ketiga rumah sakit yang mewakili semua jumlah rumah sakit ada 1 rumah sakit(1/3) tidak mempunyai pegangan lift. Jadi estimasi parameter tersebut benar.

\section{Kesimpulan}

Bedasarkan hasil penelitian yang penulis lakukan di Rumah Sakit Surakarta dapat disimpulkan sebagai berikut:

1. Berdasarkan data keseluruhan dari unsurunsur yang diteliti dari ketiga rumah sakit yang ada di surakarta bahwa penilaian tingkat keberhasilan pemakaian lift suatu

bangunan dalam memberikan kepuasan kepada pemakai terutama untuk penyandang cacat fisik adalah cukup nyaman atau cukup berhasil.

2. Berdasarkan data survey yang dilakukan pada ketiga rumah sakit maka penggunaan elevator (lift) adalah sangat vital sekitar $96,6 \%$ dalam pemakaian lift untuk kaum difabel dalam bangunan tinggi.

3. Perbedaan kenyamanan lift pada rumah sakit terutama terletak pada pegangan 7 responden yang menjawab Pegangan pada lift $(38,88 \%)$.dari 18 responden.

\section{Saran / rekomendasi}

Berdasarkan kesimpulan dan implikasi penelitian, maka beberapa saran yang perlu disampaikan adalah sebagai berikut:

\section{a. Untuk kalangan akademisi:}

Dalam penelitian selanjutnya apabila ada peneliti yang ingin melanjutkan dikaji lebih mendalam dari aspek aspek teknis maupun fungsional dalam suatu desain bangunan.

b. Untuk pengelola rumah Rumah sakit

Untuk melakukan pengelolaan yang lebih baik terhadap exsisting ruang atau bangunan

\section{c. Bagi Pemerintah Daerah}

Dimohonkan untuk memberlakukan peraturan penggunaan Lift yang standar internasional bagi kaum difabel. Sehingga peraturan itu akan berguna bagi rancangan bangunan berikutnya. 


\section{DAFTAR PUSTAKA}

Azizah, Ronim ,1999, Buku Pedoman Kuliah Utilitas, Universitas Muhammadiyah Surakarta.

Gulo, W., 2002. Metodologi Penelitian, Gramedia, Jakarta.

Juwana, Jimmy S., 2005, Panduan Sistem Bangunan Tinggi untuk Arsitektur dan Praktisi Bangunan, Erlangga, Jakarta.

Neufert, Ernst. 1995. Data arsitek, Erlangga, Jakarta.

Peraturan Menteri Pekerjaan Umum No. 30/PRT/M/2006 Tentang Persyaratan Teknis dan Aksesibilitas pada Bangunan Umum dan Lingkungan

Suryaning,S.,2008, Buku Pedoman Kuliah Aksesibilitas, Universitas Muhammadiyah Surakarta.

Undang-undang Nomor 4 Tahun 1997 Tentang Penyandang Cacat

www.wikipedia.com. Elevator.

www.wikipedia.com.Kursiroda 